\title{
Morphology and structure of the 1999 lava flows at Mount Cameroon Volcano (West Africa) and their bearing on the emplacement dynamics of volume-limited flows
}

\author{
C. E. SUH* ${ }^{*}$, S. A. STANSFIELD $\dagger$, R. S. J. SPARKS $\dagger$, M. S. NJOME $\ddagger$, \\ M. N. WANTIM $\ddagger \S \&$ G. G. J. ERNST \\ *Economic Geology Unit, Department of Geology and Environmental Science, University of Buea, \\ P.O. 63 Buea, Cameroon \\ †Department of Earth Sciences, University of Bristol, Wills Memorial Building, Queens Road, Bristol, BS8 1RJ, UK \\ $\ddagger$ Department of Geology and Environmental Science, University of Buea, P.O. 63 Buea, Cameroon \\ $\S$ Department of Geology and Soil Science, University of Ghent, Krijgslaan 281, S8; B-9000 Ghent, Belgium \\ \Mercator and Ortelius Research Centre for Eruption Dynamics, Department of Geology and Soil Science, University \\ of Ghent, Krijgslaan 281, S8; B-9000 Ghent, Belgium
}

(Received 7 May 2009; accepted 16 November 2009; first published online 4 May 2010)

\begin{abstract}
The morphology and structure of the 1999 lava flows at Mount Cameroon volcano are documented and discussed in relation to local and source dynamics. Structures are analysed qualitatively and more detailed arguments are developed on the processes of levee formation and systematic links between flow dynamics and levee-channel interface geometry. The flows have clear channels bordered by four main types of levees: initial, accretionary, rubble and overflow levees. Thermally immature pahoehoe lava units with overflow drapes define the proximal zone, whereas rubble and accretionary levees are common in the distal region bordering thermally mature aa clinker or blocky aa flow channels. Pressure ridges, squeeze-ups and pahoehoe ropes are the prevalent compressive structures. Standlines displayed on clinkery breccias are interpreted to represent leveechannel interactions in response to changing flow levels. These data complement previous knowledge on lava flow morphology, thus far dominated by Etnean and Hawaiian examples.
\end{abstract}

Keywords: Mount Cameroon volcano, lava flows, morphology.

\section{Introduction}

Detailed studies of basaltic or basaltic andesite lava flows have been dominated by investigations at only a few volcanoes, for example, Hawaiian volcanoes (Soule, Cashman \& Kauahikaua, 2004; Harris et al. 2009; Ball, Pinkerton \& Harris, 2008), Longquimay, Chile (Naranjo et al. 1992) and Etna, Italy (Polacci \& Papale, 1997, 1999; Calavari \& Pinkerton, 1998, 1999; Guest et al. 1987; Guest \& Stofan, 2005; Bailey et al. 2006). There is need to examine case studies elsewhere. Studies focused on lava flow emplacement dynamics can help volcanologists understand and predict the kinematics of lava flows (e.g. Pinkerton \& Sparks, 1976; Peterson \& Tilling, 1980; Kilburn, 1990; Kilburn, Pinkerton \& Wilson, 1995; Polacci \& Papale, 1997; Self, Keszthelyi \& Thordason, 1998; Self et al. 2008; Keszthelyi \& Self, 1998; Cashman, Thornber \& Kauahikaua, 1999; Guest \& Stofan, 2005). Estimates of lava velocity, direction and extent can aid in hazard mitigation.

Mount Cameroon (Fig. 1a, b) is one of the most active of Africa's volcanoes, with seven eruptions in the last 100 years. At Mount Cameroon, the well-exposed 1999 lava flows are not yet extensively colonized by vegetation and are well suited for field investigation

*Author for correspondence: chuhma@yahoo.com of lava flow attributes. Aspects of the 1999 eruption have been documented previously (Suh et al. 2003; Suh, Luhr \& Njome, 2008). No detailed study has yet described the physical aspects of the 1999 lava flows, nor attempted to relate morphological features and flow structures to emplacement history and processes. This contribution documents the range of flow-types, morphologies and structures observed for the 1999 Mount Cameroon lava flows, and qualitatively assesses their development.

\section{Geological context of Mount Cameroon and the 1999 eruption}

Mount Cameroon is a steep, lava-dominated volcano, situated at $4.20^{\circ} \mathrm{N}, 9.17^{\circ} \mathrm{E}$ (height: $4095 \mathrm{~m}$ a.s.l.) in SW Cameroon (Fig. 1b). Suh et al. (2003) estimated the volume of this volcano at $1200 \mathrm{~km}^{3}$. In plan form, Mount Cameroon is elliptical; $50 \mathrm{~km}$ long in a NESW direction, and $35 \mathrm{~km}$ wide in a NW-SE direction. The Mount Cameroon edifice surface is dominantly covered by basanite and hawaiite lavas and subsidiary fall-out tephra deposits. Recent $\mathrm{K}-\mathrm{Ar}$ dates on seven mafic lava samples yielded ages between $2.83 \pm 0.11$ and $0.00 \pm 0.09 \mathrm{Ma}$ (Wandji et al. 2009). Though weak Strombolian activity is observed, effusive eruption of lavas is the dominant phenomenon. Over 200 scoria 

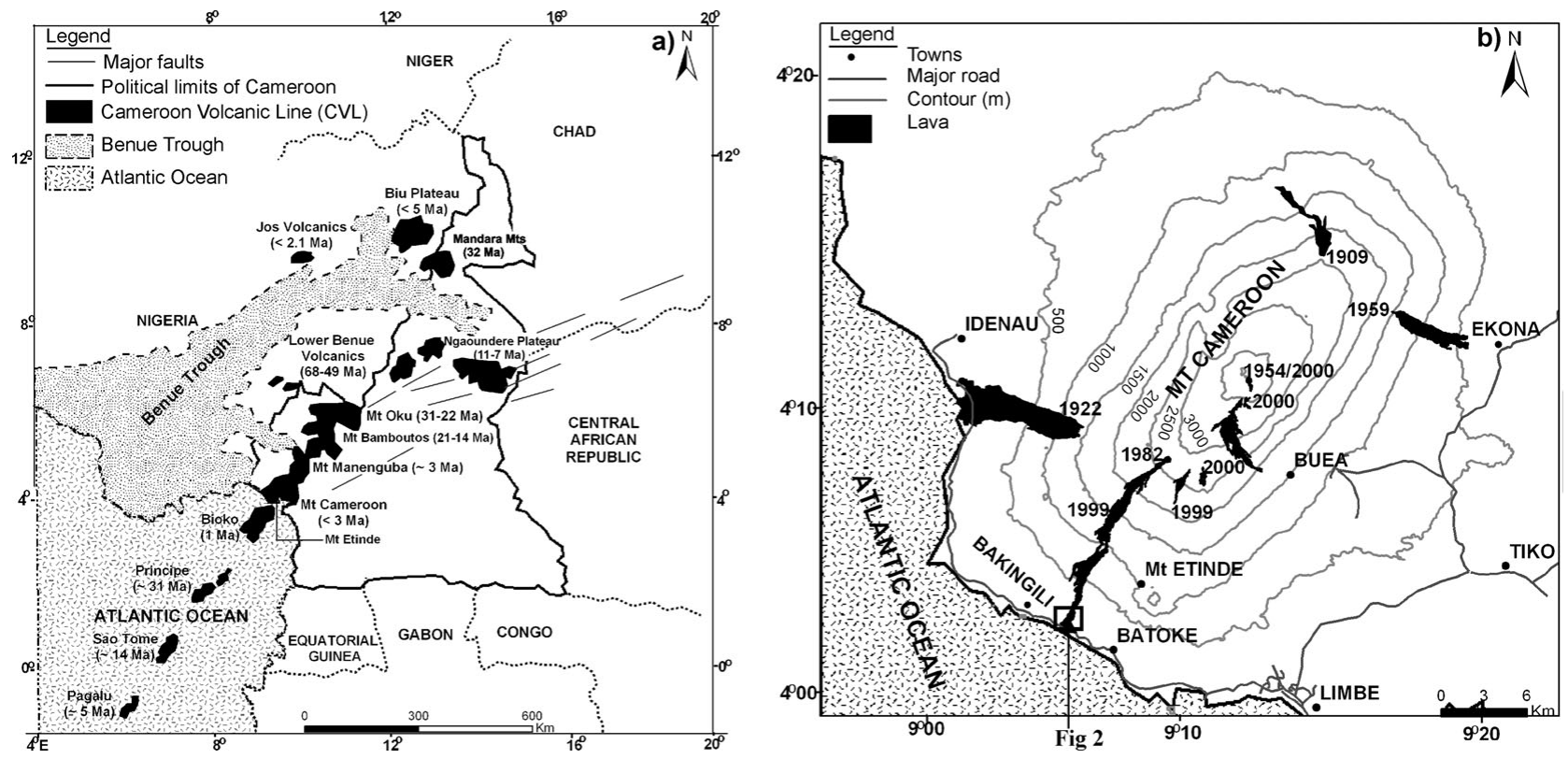

Figure 1. (a) Sketch map of the Cameroon volcanic line (CVL) showing the location of Mount Cameroon along this SW-NE-trending volcanic chain. (b) Contour map of Mount Cameroon displaying the 20th century lava flows (after Suh et al. 2003). Location of Figure 2 at the distal end of the 1999 flow is indicated in the box outline.

cones can be identified, for example, on remote-sensing imagery, at Mount Cameroon, defining a NE-SW trend along the Cameroon Line, a $1600 \mathrm{~km}$ long linear volcanic zone that stretches from maritime Pagalu in the SW to Biu in NE Nigeria (Fig. 1a).

The Cameroon Line (Déruelle, Ngounouno \& Demaiffe, 2007 and references therein) is divided into two provinces: oceanic (dominantly basaltic with minor nephelinite, phonolite and trachyte lavas: Fitton, 1987; Fitton et al. 1983; Fitton \& Hughes, 1977; Halliday et al. 1988) and continental (with a wider suite of rocks and age range, including felsic and basaltic lavas, and more silicic and alkaline plugs: Nono et al. 1994; Marzoli et al. 2000; Ngounouno, Deruelle \& Demaiffe, 2000). The volcanic products are deposited on Tertiary sediments overlying a Precambrian crystalline basement (Toteu, Penaye \& Poudjom Djomani, 2004; Ngako et al. 2006), or intrusive syenites and granites younger than $70 \mathrm{Ma}$. Magma ascent in the NE section of the continental province was focused along a fracture zone (Poudjom Djomani et al. 1997).

Details of the 1999 eruption are presented in Suh et al. (2003). Following precursory earthquake swarms on 26-27 March 1999, the eruption occurred between March 28 and April 22 from two collections of vents at different elevations. The first set of vents, named site 1 , opened at $\sim 2807 \mathrm{~m}$ on March 28, and erupted both explosively and effusively. On March 30, a second set of vents, named site 2 , opened at $\sim 1545$ m elevation. Site 1 lava flows have final dimensions of $3 \mathrm{~km}$ long, 30$120 \mathrm{~m}$ wide and with flow fronts $15 \mathrm{~m}$ high; Suh et al. (2003) estimated their volume as $\sim 2.7 \times 10^{6} \mathrm{~m}^{3}$. The lava effusion rates varied in the course of the eruption between 4.8 and $9.8 \mathrm{~m}^{3} \mathrm{~s}^{-1}$. The main site 2 lava flow front extended about $10 \mathrm{~km}$ with dimensions $\sim 400 \mathrm{~m}$ wide by $\sim 10 \mathrm{~m}$ thick, indicating a lava volume of $\sim 4 \times 10^{7} \mathrm{~m}^{3}$ (Suh et al. 2003). An average effusion rate of $40 \mathrm{~m}^{3} \mathrm{~s}^{-1}$ was determined for the duration of the eruption from site 2. At site 2 , over a dozen flow velocity measurements, ranging between $6.9 \times$ $10^{-4} \mathrm{~m} \mathrm{~s}^{-1}$ and $5 \mathrm{~m} \mathrm{~s}^{-1}$, were recorded from 5 to 15 April 1999 (Fig. 2).

The 1999 lavas are basanites $\left(44-47 \% \mathrm{SiO}_{2}\right)$ with occasional hawaiites (Suh et al. 2003; Suh, Luhr \& Njome, 2008; Njome et al. 2008). The lava is porphyritic with olivine $(8 \%)$, clinopyroxene $(5 \%)$, plagioclase $(3 \%)$ and titanomagnetite $(1 \%)$ phenocrysts set in a fine-grained, often partly glassy groundmass $(83 \%)$. Blocks of massive, non-vesicular lava have a mean density of $2592 \mathrm{~kg} \mathrm{~m}^{-3}$. Application of the olivine geothermometer (Roedder, 1974) infers a pre-eruptive temperature of $1166^{\circ} \mathrm{C}\left( \pm 30^{\circ} \mathrm{C}\right)$. In contrast, residual hawaiite melt (Suh et al. 2003), in equilibrium with more fayalitic microlites and phenocryst rims, gives an eruption temperature of $1042{ }^{\circ} \mathrm{C}\left( \pm 30^{\circ} \mathrm{C}\right)$, with measured temperatures of hawaiite lavas on Etna of $1070-1090{ }^{\circ} \mathrm{C}$ (Pinkerton \& Sparks, 1976). Suh et al. (2003) measured field temperatures of $950-975^{\circ} \mathrm{C} 40 \mathrm{~cm}$ into the stagnant site 1 flow fronts (4 April) and $1000^{\circ} \mathrm{C}$ at the site 2 lava fronts $\sim 10 \mathrm{~km}$ from the fissure (10 April), providing lower bounds on the lava temperature. With these temperatures and compositions, one can estimate lava viscosity. Using the empirical method of Shaw (1972), a residual melt of hawaiite composition at between $1012{ }^{\circ} \mathrm{C}$ and $1072{ }^{\circ} \mathrm{C}$ yields a viscosity of between 145 and $320 \mathrm{~Pa}$ s. Lava composed of $17 \%$ phenocrysts and $83 \%$ residual hawaiite has an estimated viscosity of $\sim 320-710 \mathrm{Pas}$ in the 1012 to $1072{ }^{\circ} \mathrm{C}$ temperature range, whereas the composition of matrix glass (Suh et al. 2003) yields viscosity for the residual melt of between $3.2 \times 10^{6}$ and $10^{6} \mathrm{Pas}$ for the temperature 


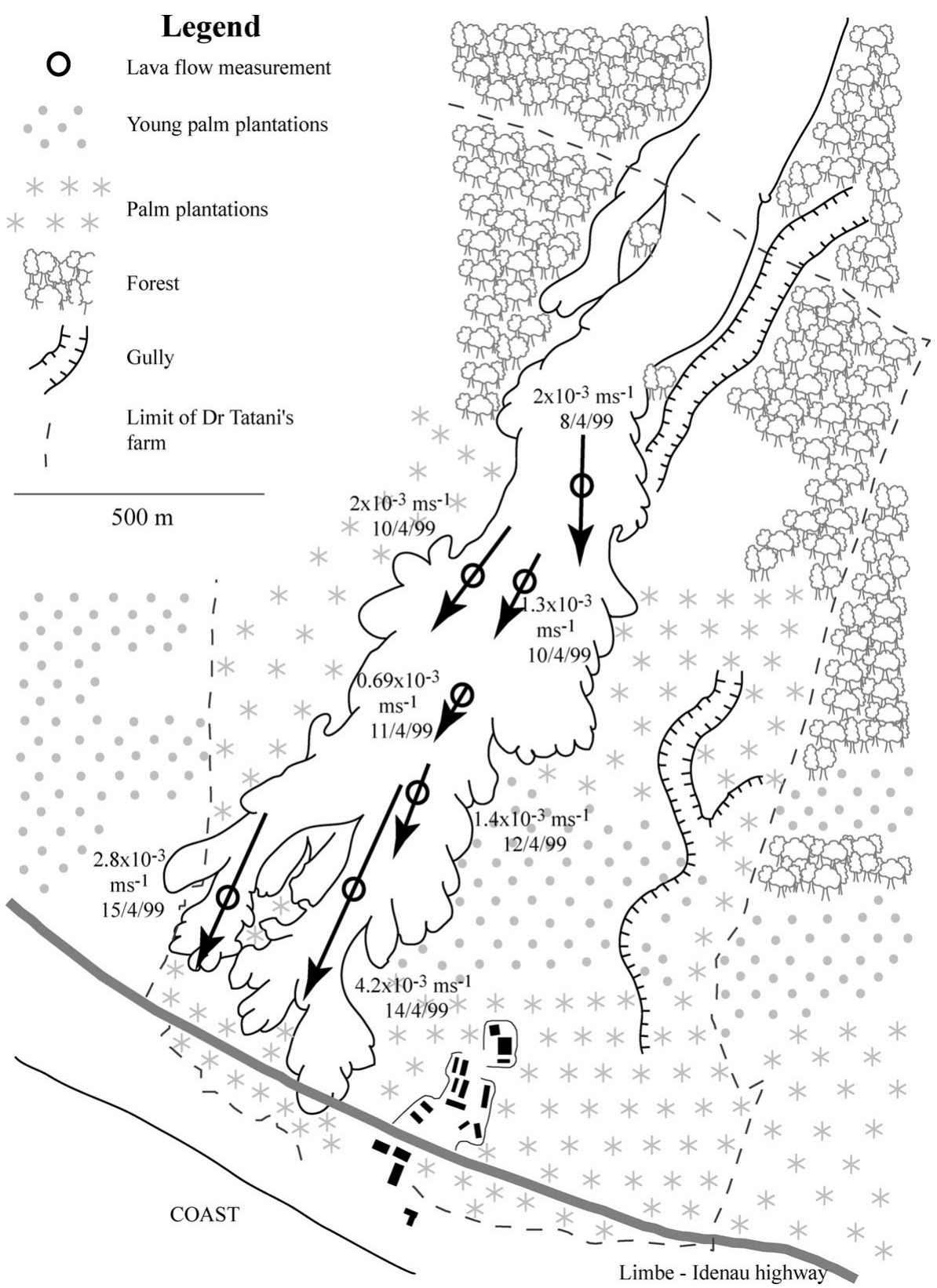

Figure 2. Map of the distal regions of the main site 2 flow-fields, near Bakingili, with flow velocities for different dates indicated. North is top of the figure.

range $950{ }^{\circ} \mathrm{C}$ to $1000^{\circ} \mathrm{C}$. Estimate of apparent viscosity of the 1999 lava flow fronts is in the order of $10^{8} \mathrm{~Pa} \mathrm{~s}$ from application of the Jeffreys equation to data on frontal speeds, thicknesses and slopes.

\section{Lava flow morphology, field textures and structures: field methods}

Transverse profiles (cross-sections from one flow margin to the other) were documented for 20 lava sections (online Appendix 1 at http://www.cambridge. org/journals/geo) by field surveys, using a tape measure, compass and an abney level. There are no accurate maps or DEM (digital elevation models) of the preeruption topography. Where possible, the contact with the underlying pre-eruption topography was evaluated using marginal levee-topography contact geometry.

\section{Results and interpretations}

\section{4.a. Large-scale morphology: levees and channels}

The lava cross-sections reveal that the flows have single (or multiple) channel(s) (Appendix 1 at http:// www.cambridge.org/journals/geo), bounded by welldefined levees. An active channel is a stream of lava contained within marginal zones of static lava termed levees (cf. Harris et al. 2009). Channel width varies greatly; proximal pahoehoe channels (Fig. 3a, b) are much narrower than distal blocky aa channels (some over $100 \mathrm{~m}$ wide, Fig. 3c). Successive sets of levees are commonly encountered as one passes from a flow margin to its centre and the final end-of-eruption channel surface (Fig. 3d). These stranded levee sequences are interpreted to represent an overall decrease in local flow rate over time. The outermost flow-unit bordering 
(a)
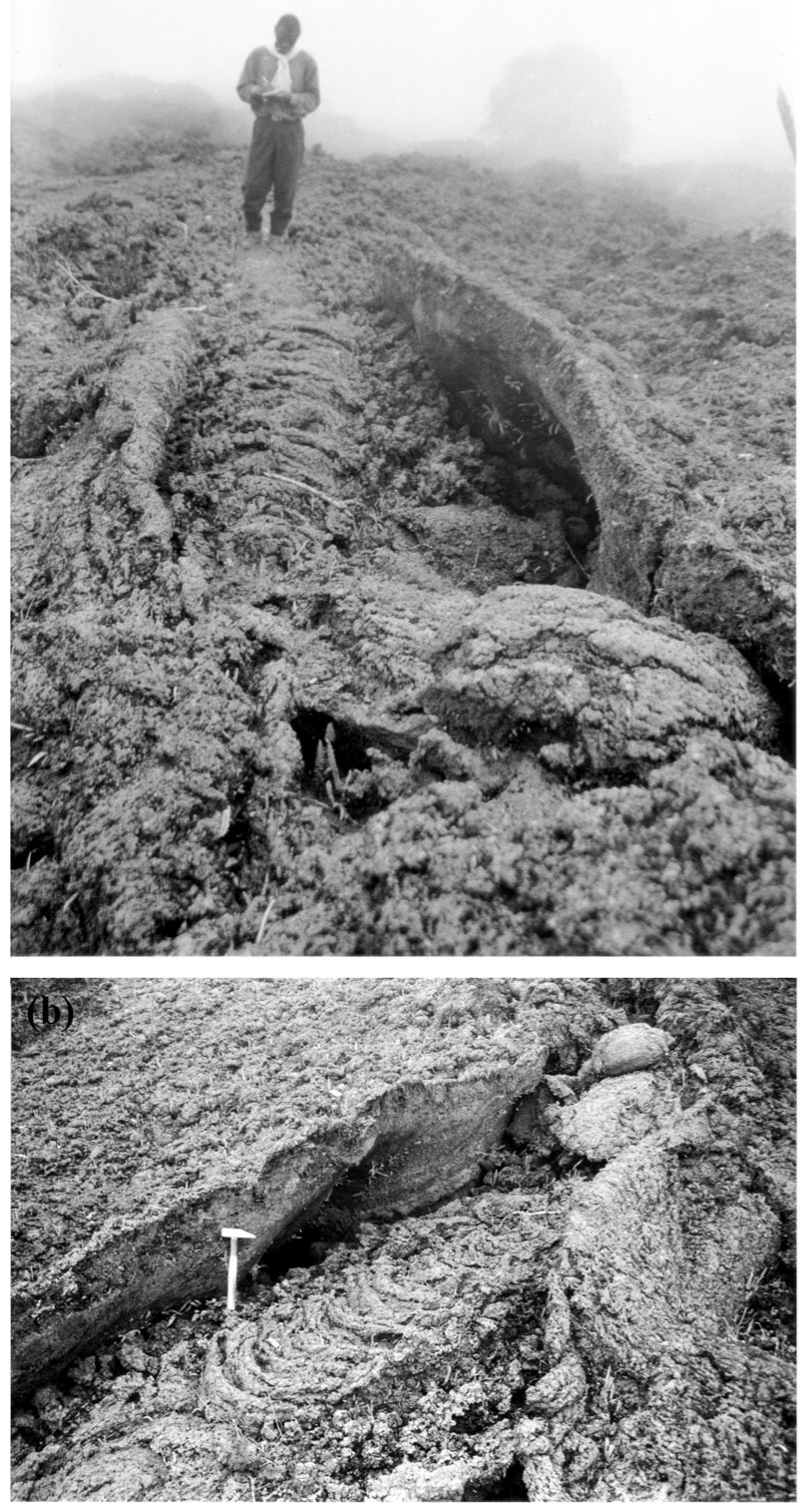

(c)

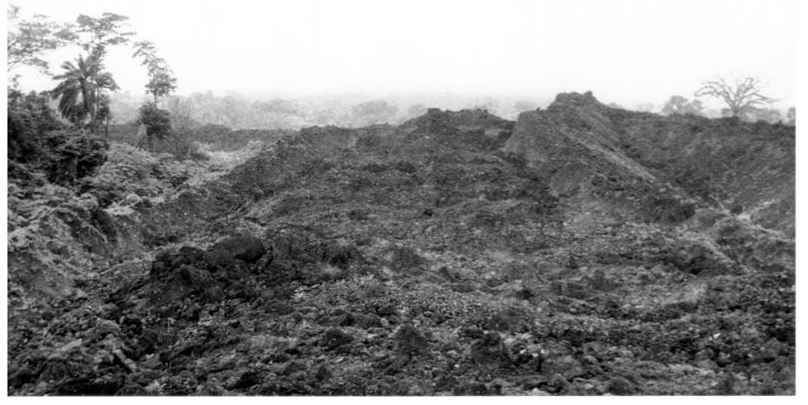

(d)
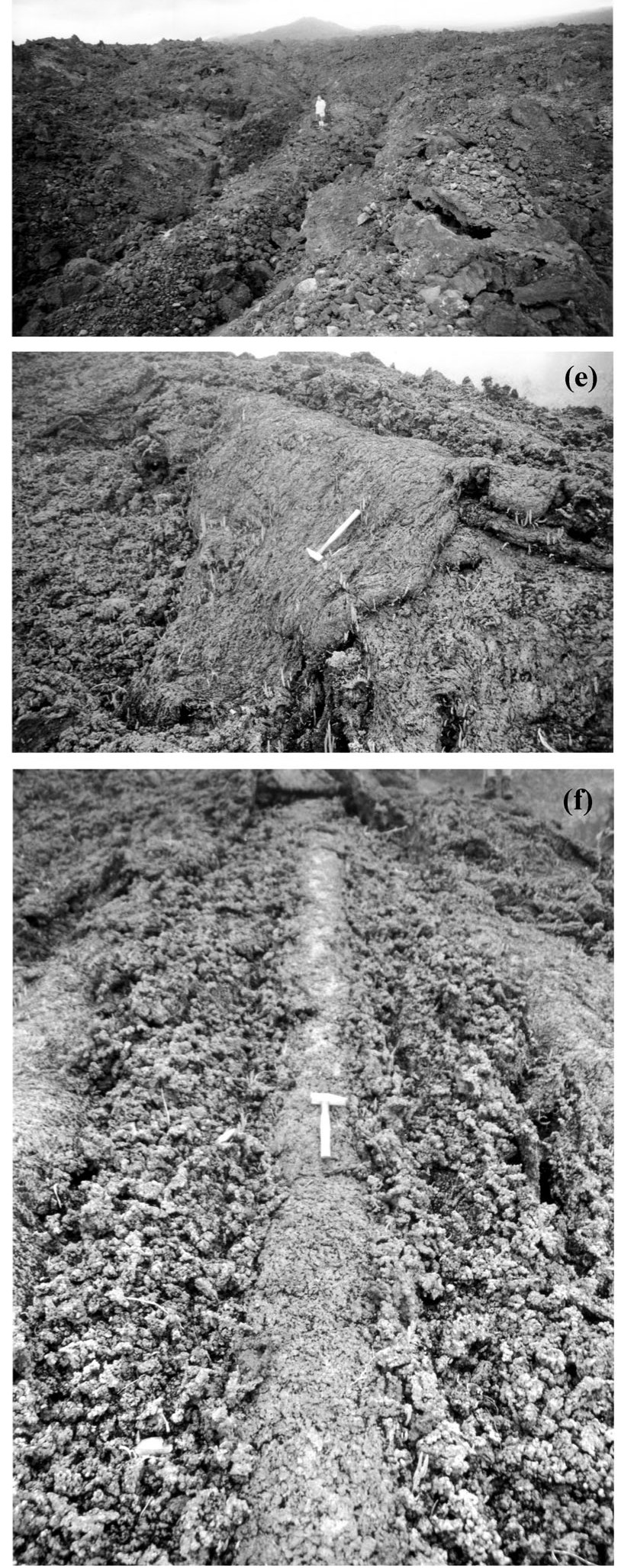

Figure 3. Typical large-scale features of the Mount Cameroon 1999 lava flows. (a) Proximal pahoehoe channel emerging from a near-source bocca, by the site 2 vents. (b) Accretionary levees developed in a small, proximal bocca-fed lava channel, near the site 2 vents. The central pahoehoe is flanked by clinker. The levees also display evidence of overflow activity, indicating a more complex, compound structure; hammer is $\sim 40 \mathrm{~cm}$ long. (c) Distal blocky aa flow channel, near Bakingili. The central flow depicted is $\sim 100 \mathrm{~m}$ wide. (d) Sequence of stranded levees. Photo is taken looking up flow with figure standing on an interior levee, bounding the main flow channel to the left. (e) Pahoehoe overflow levee with thin drape. (f) Thermally immature aa clinker features. The central region of pahoehoe is $50 \mathrm{~cm}$ at its greatest extent, and grades from a ropy facies into slabby, fractured pahoehoe downstream. The change to disaggregated aa clinker at the pahoehoe margins is abrupt. 
levees form first and, as the active flow region narrows and thickens, the marginal levees are constructed. The highest point of the outer levee marks the high-stand line for the lava. As this channel drains, lava leaves the outermost levee stranded. Internal levees can be formed through a variety of processes. Typically they represent subsequent flow pulses, or further inflation in the channel through rheological stiffening down-slope exerting a local back-pressure, which in turn leads to lava flow thickening (Harris et al. 2009). The draining of this channel would expose another set of younger levees, and so the process can continue.

Some profiles (Appendix 1 at http://www. cambridge.org/journals/geo) lack clear levees, and these are only a few metres ( 1 to $3 \mathrm{~m}$ ) back from the flow front, corresponding with the zone of dispersed flow, or 'flow toe', as described by Lipman \& Bank (1987).

\section{4.b. Small-scale morphology: textural characteristics of pahoehoe, aa and blocky lavas}

\section{4.b.1. Pahoehoe}

Site 1 or 2 pahoehoe flows locally occur near the vents and are examples of thermally immature lavas (Fig. 3a, b). Having cooled little, they deform in a ductile fashion, forming ropes and folds on an otherwise relatively smooth surface (e.g. Fink \& Fletcher, 1978; Fink, 1980). Surface samples consist of glassy, vesicular pahoehoe, with a finely drawn-out, bladed surface texture (Kilburn, 1990). Blades are highly deformed, typically $2-4 \mathrm{~mm}$ in relief and contiguous for $1-2 \mathrm{~cm}$, and commonly carry millimetre- and sub-millimetresized parasitic stubbly spines and knobs. Pahoehoe drapes (Fig. 3e) show a deformed, finely filamented and platy surface, with filaments of millimetre-relief changing direction over lengths of $\sim 3 \mathrm{~cm}$.

\section{4.b.2. Clinker aa}

Thermally immature aa displays typical irregular clinker appearance (Fig. 3f), analogous to the cauliflower aa of Kilburn (1990). The lava forms an irregular surface habit reminiscent of a 'field of maltreated cauliflowers', with aa forming small, irregular protrusions in the order of 1 to $10 \mathrm{~cm}$ in size, with similar inter-cauliflower distances, and a typical relief of 5 to $20 \mathrm{~cm}$. The surfaces of cauliflowers and florets are composed of millimetre-sized spines that display a bladed ('stiletto') or stubby habit similar to Mt Etna lavas (Kilburn, 1990).

\section{4.b.3. Blocky aa}

Thermally mature blocky aa is typically composed of a variety of clasts: abraded clinker, fractured angular blocks of massive lava or welded breccia fragments (Fig. 4a, b). The propensity of breccia facies and massive lava increases with increasing distance from the vent. Most large cauliflowers retain

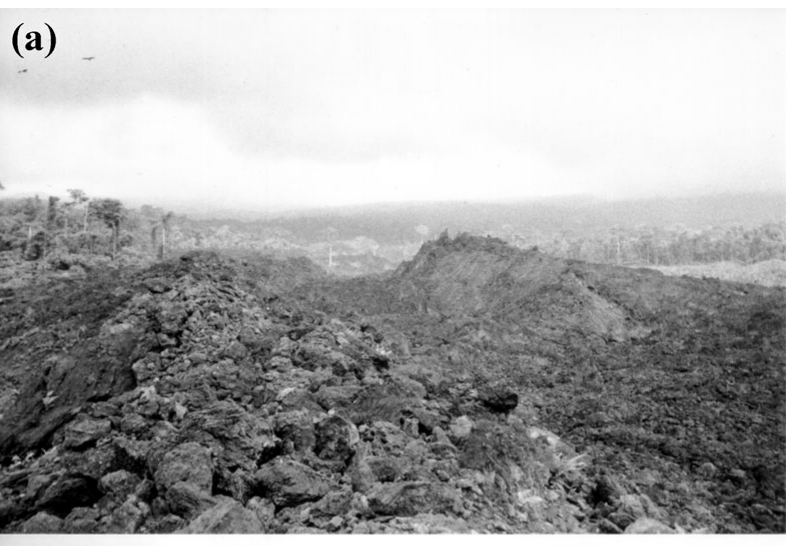

(b)

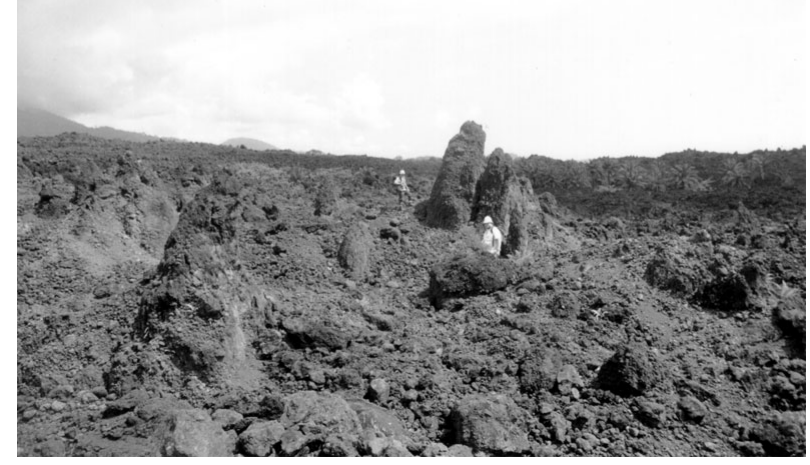

Figure 4. Detailed characteristics of block aa lavas of the 1999 Mount Cameroon flows. (a) Large blocky lava channel bordered by rubble levees, at the Bakingili lava fronts (looking upstream, NNE). Boulders in left foreground are $\sim 50 \mathrm{~cm}$ across. (b) Upthrown slabs or spinacles of welded flow breccia/rubble, thrust out of the central region of a blocky channel of the distal site 2 flows near Bakingili. The men are $\sim 170 \mathrm{~cm}$ tall.

their characteristic morphology, having fractured into small blocks. Blocky aa varies between clast- and matrix-supported, and clasts may be angular, stubby or rounded. The matrix consists of fine to medium sandgrade material, and many clasts appear to be reworked granules of earlier breccias.

\section{4.c. Levee structure and texture}

The 1999 flows of Mount Cameroon illustrate a diversity of levee types, and partial draining of some channels allows observation and analysis of their internal structure. These levees can be either 'external', that is, bounding a discrete flow unit (Fig. 5a), or 'internal', where they lie within the flow profile itself, as a secondary construct. Four archetypes of levees described by Sparks, Pinkerton \& Hulme (1976) are present, to varying degrees and combinations, in the 1999 flows.

\section{4.c.1. Initial levees}

Initial levees (static lava due to passage of the parental flow: Pinkerton \& Sparks, 1976; Lipman \& Banks, 1987) are rarely preserved. They were observed to form on Mount Etna (Pinkerton \& Sparks, 1976), but were 

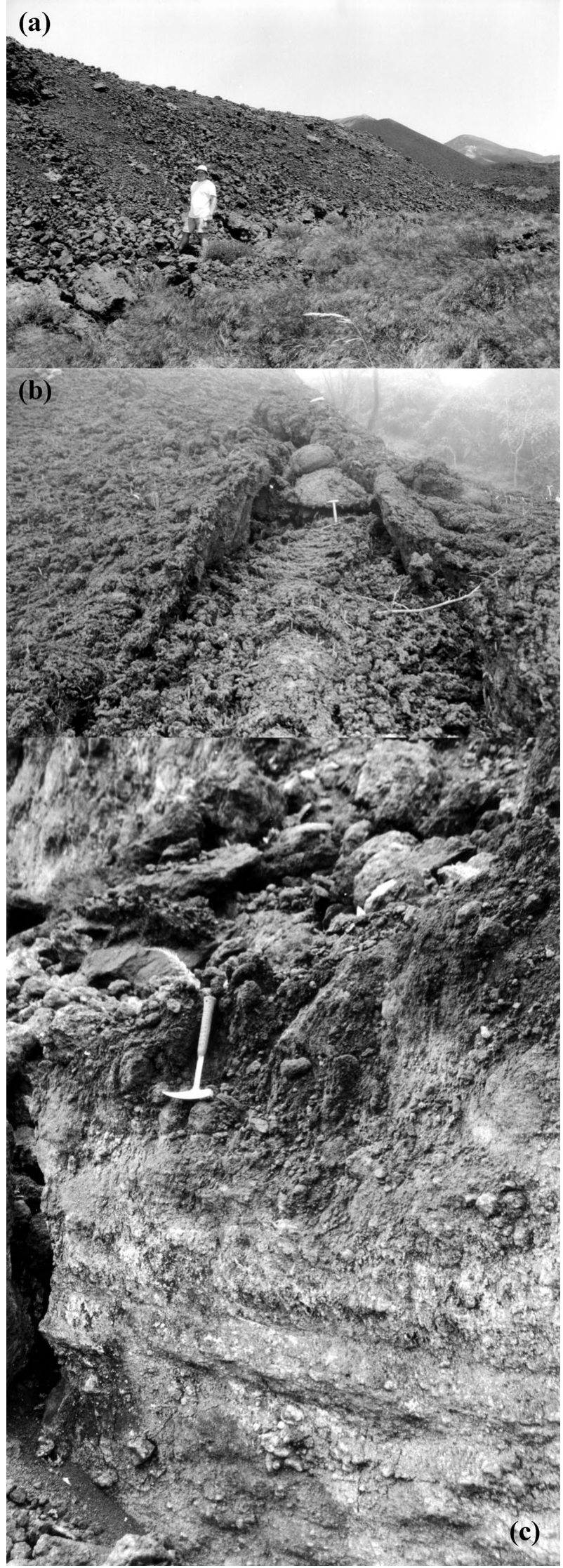

Figure 5. Main levee types of the 1999 lava flows at Mount Cameroon volcano. (a) Outer rubble levee wall displaying typically loose (unconsolidated) angle-of-rest talus. The level of sorting in the marginal talus slopes varies considerably. The person is $\sim 175 \mathrm{~cm}$ tall. (b) Accretionary levees developed in a small, bocca-fed lava channel. Hammer is $\sim 40 \mathrm{~cm}$ long. always destroyed by subsequent levee-forming processes. Naranjo et al. (1992) described well-preserved initial levees composed of massive andesite lava at Lonquimay volcano, Chile. The greater shear rate and high flow velocities of the Cameroon basalts compared to the low effusion rate Etna lavas studied by Pinkerton \& Sparks (1976) lead to a different dynamic regime. Initial, incandescent visco-plastic levees on $\mathrm{Mt}$ Cameroon cool rapidly and fracture. Furthermore, the welding of marginal clinkers or actions of localized flow surges can overprint them with an 'accretionary' or 'overflow' character. Rarely, the emptying of both proximal and distal channels reveals massive lava on internal levee walls, underlying areas of welded breccia, clinker or overflow drapes. Such material is typically striated, and hence represents remnants of initial levees.

\section{4.c.2. Accretionary levees}

Accretionary levees are commonly preserved (Fig. 5b), and many have outwardly sloping inner walls (Fig. 5c). While the upper portions of the levees are welded clinker, more solid lava lies below the accretionary structures, with pahoehoe overflows draping them. Polacci \& Papale (1997) describe long undulations (with axial trace parallel to flow direction) in the nearbocca flows of Mt Etna, wherein the marginal clinker overlies solid lava ridges.

\section{4.c.3. Rubble levees}

Rubble levees (Fig. 5a) are composed of highly brecciated clinker and blocks, which can be loose, packed or commonly welded. Typically the levee will display two distinct parts: a more gentle outer slope (Fig. 5a) and a steeper inner wall (Fig. 5c). These sectors and their characteristic facies are shown in Figure 6. The lower outer slopes of external (flow bounding) levees are composed of loose, unconsolidated talus (Figs 5, $6)$. The size of the material varies from sub-millimetresized coarse sand, through granules and small blocks, to larger blocks and metre-sized boulders. Clasts are typically subangular to rounded, and the whole deposit is moderately to poorly sorted. There is typically a slight decrease in mean grain size down the outer levee. The upper portion of the outer slope is composed of welded clinkery rubble and breccia (Fig. 6). This material is dominantly the same facies as is seen on the inner wall: it may be solid, fractured or wholly disaggregated

(c) Steep inner wall of a rubble levee at the distal Bakingili flow fronts. The material here consists of a fine, matrix-supported welded breccia at the base, which grades upwards into a deposit of incipiently welded aa clinker and rubble. The clinkery breccia displays several 'standlines', typically $10 \mathrm{~cm}$ apart, interpreted as levee-channel interactions in response to changing flow level. The welded clinker grades into a less consolidated breccia richer in fines, and ultimately into a clast-rich rubbly top. Hammer is $\sim 40 \mathrm{~cm}$ long. 


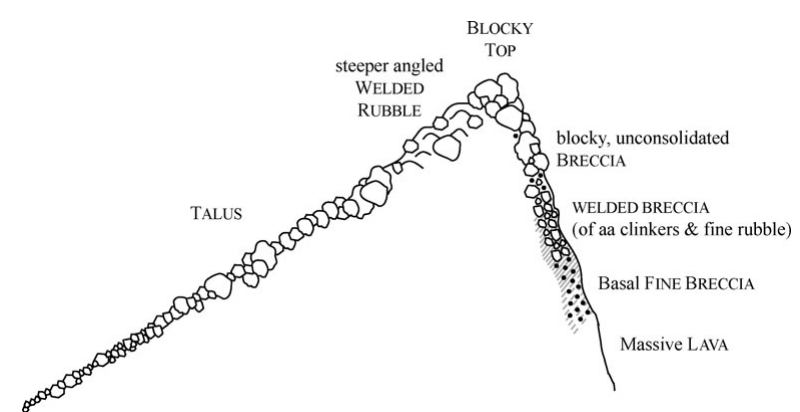

Figure 6. Typical rubble levee geometry and structure of the 1999 lavas. This sketch shows the various textural facies and their spatial occurrence in typical rubble levees.

into large blocks. Where solid, it typically stands out above the lower talus apron at slopes of $45^{\circ}$ to $60^{\circ}$, well above the angle of rest. This 'outer top' welded rubble facies may account for 10 to $40 \%$ of the outer slopes' length; a mix of $66 \%$ talus and $33 \%$ welded breccia is typical. The welded breccia is typically overlain at the top by poorly sorted, unconsolidated angular blocks of rubble and massive lava. Such material is typically coarser ( $>10 \mathrm{~cm}$ across) and more angular than the outer levee talus.

Below the above-described blocky top is a section of blocky, unconsolidated breccia, fining downwards. In some levee walls, this material grades rapidly into a poorly sorted, matrix-supported breccia, with partial, incipient welding (Fig. 6). These facies are similar to the basal breccia of Naranjo et al. (1992), but display a far greater variety of clast size and heterogeneity. The degree of welding varies greatly, with some blocks and rubble held in place by little more than a semiconsolidated sandy matrix.

Our observations (Figs 5,6) suggest that the loose talus component of rubble levees is less significant than originally envisaged by Sparks, Pinkerton \& Hulme (1976). The levees are predominantly composed of partly to densely welded breccia and clinker, and some contain a massive core.

\section{4.c.4. Overflow levees}

Overflow levees are observed in near-vent or bocca flows and they are defined by thin pahoehoe drapes that cover existing initial or accretionary levees (Fig. 3e). The drapes are usually $15-30 \mathrm{~cm}$ thick and only travel approximately 2 to $3 \mathrm{~m}$ down existing levee slopes.

\section{4.d. Lava channels}

The geometry and morphology of channels display a strong variance between proximal and distal channel facies as the character of levees varies according to proximity to the bocca or vent. Most channels experienced repeated episodes of filling, inflation and drainage.

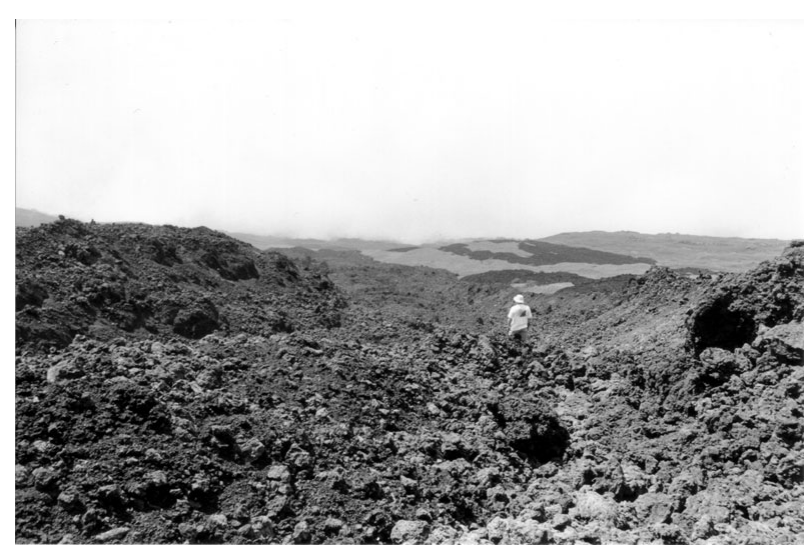

Figure 7. Aa channel from site 1 flow. The channel surface is composed of highly irregularly formed, variably spinose, jagged and scoriaceous clinkers of aa, $1-50 \mathrm{~cm}$ in diameter.

\section{4.d.1. Pahoehoe channels}

Proximal pahoehoe channels occur by the site 1 and site 2 vents, and at related boccas (Fig. 3). Bounded by initial, accretionary or overflow levees, pahoehoe channels are typically narrow $(<2 \mathrm{~m}$ wide at site $2, \sim 6 \mathrm{~m}$ wide at site 1 ), and relatively thin, 15$30 \mathrm{~cm}$ thick. The surfaces of these proximal channels commonly are zoned with a central region of ropy or slabby pahoehoe, bordered by heavily sheared aa clinker margins (Fig. 3f). The central, ropy pahoehoe is typically no wider than $50 \mathrm{~cm}$ in a channel $\sim 2 \mathrm{~m}$ wide. To either side there is an abrupt transition from pahoehoe into variably disaggregated clinker. The proximal ropy pahoehoe facies grades into slabby, fractured pahoehoe 10 to $15 \mathrm{~m}$ downstream.

\section{4.d.2. Aa channels}

Aa channels (Fig. 7) display a surface morphology dominated by scoriaceous and classic clinkery aa (e.g. Macdonald, 1953; Lipman \& Banks, 1987; Kilburn, 1990). The channel surface comprises a highly irregular form of variably spinose, jagged, scoriaceous and/or roughly angular lava. The clasts can be wholly loose and disaggregated, welded or massive and deeply rooted into the flow interior (Jaggar, 1930). Typically, clinkers are 0.02 to $0.5 \mathrm{~m}$ across, and overlie more massive lava interior (as seen by Macdonald, 1945). Aa channels are typically accompanied by accretionary or rubble levees. Whereas pahoehoe is usually characterized by a single, clearly defined channel, distal aa channels commonly possess a hummocky appearance.

\section{4.d.3. Blocky aa channels}

These channels are exemplified by the most distal 1999 flow front (hereafter referred to as the Bakingili flow front; Fig. 4), with a series of interdigitating flow lobes outlining a flow field $\sim 500 \mathrm{~m}$ wide at its greatest lateral extent. In contrast to the aa flows, the surface is unconsolidated, consisting of angular to 
rounded blocks of massive lava and welded breccia (0.1-2 m). Occasional rafts of welded breccia up to $4 \mathrm{~m}$ high thrust out through the surface rubble (Fig. 4b). The transition from clinkery aa channel surfaces to blocky aa is gradual. Clinker surfaces form as hot visco-plastic lava wells up between fractures or existing aa cauliflowers, or form as consolidating clots in more incandescent fluid flows (e.g. Macdonald, 1953; Peterson \& Tilling, 1980; Lipman \& Banks, 1987; Kilburn, 1990). The clinker clasts are further milled and fragmented after formation. As aa surfaces develop and thermally mature, the underlying lava cools to the extent that it becomes a brittle solid; deformation subsequently results in fragmentation of the cooled surface region to form blocks.

\section{4.e. Compression-induced structures \\ 4.e.1. Pahoehoe ropes}

Pahoehoe ropes are common in proximal regions (Fig. 3a). Twenty well-formed ropes present in a $2 \mathrm{~m}$ section imply a mean wavelength of $10 \mathrm{~cm}$. The ropes typically display amplitudes of $5 \mathrm{~cm}$ on average (to a maximum of $10 \mathrm{~cm}$ ). Ropes are compressive folds developed on still ductile cooled surfaces (Fink \& Fletcher, 1978; Fink, 1980; Gregg, Fink \& Griffiths, 1998).

\section{4.e.2. Pressure ridges}

Pressure ridges are exposed as rubbly linear hummocks, contiguous over distances ranging from a few metres to several tens of metres, displaying an orientation which varies from parallel to the channel sides to perpendicular to the flow direction along the channel centreline (Fig. 8a, b). They are commonly observed following a reduction in slope. A decrease in the angle of slope underlying a site 1 flow (Fig. 8a), from $17^{\circ}$ to $6^{\circ}$, produced three well-developed transverse pressure ridges, with amplitudes of $0.6,1.3$ and $1.5 \mathrm{~m}$, and average wavelength of $8.2 \mathrm{~m}$. The side arms of the ridges slope at $\sim 24^{\circ}$.

\section{4.e.3. Squeeze-ups}

Squeeze-up features, consisting of more thermally immature lava pushed through the solid/blocky flow carapace, are commonly observed, particularly in the blocky aa flows near Bakingili where a prominent ridgelike lobe of clinker aa $\sim 5 \mathrm{~m}$ wide squeezes out between two adjacent lobes of blocky aa (Fig. 9a, b). The ridge's structure consists of a spinose, vesicular clinker aa overlying a core of solid massive lava. This lava displays well-developed lineations: near-horizontal striations in the flow direction, and sub-vertical, shallow tensile fractures a few centimetres deep. Eruptional visual evidence states that the blocky aa lobes were emplaced first, and the clinker squeezed out of the gap between them as the flow advanced. (a)

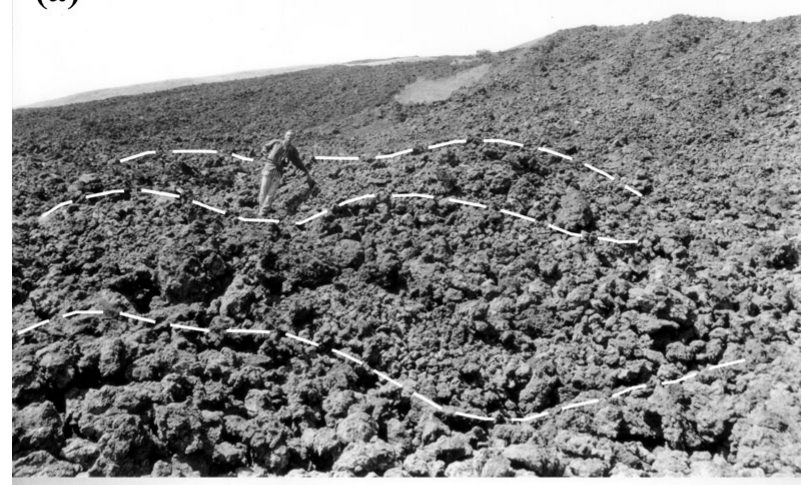

(b)

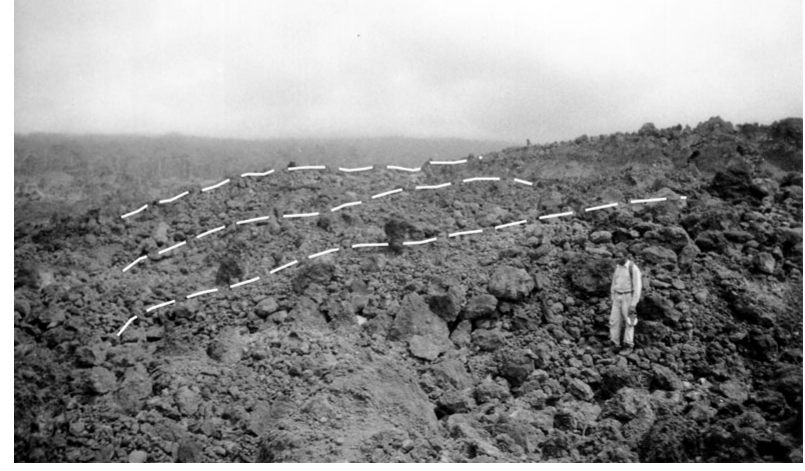

Figure 8. Main types of pressure ridges of the 1999 Mount Cameroon lava flows. (a, b) Pressure ridges in a site 1 transitional blocky aa channel (the person leans against one ridge, with crests of three ridges highlighted). Average structure wavelength is $8.2 \mathrm{~m}$; photo looking upstream.

\section{4.e.4. Flow fronts}

Flow fronts of more thermally immature aa flows comprise poorly sorted $(5-100 \mathrm{~cm})$, occasionally welded clinker, with large cauliflowers and finer abraded and brecciated clasts. These less-developed aa flows have heights of up to 1 to $2.2 \mathrm{~m}$. The most distal thermally mature blocky aa flows develop highly irregular, poorly sorted blocky fronts (Fig. 10a, b, c), with a significant level of fine sand and dust. Large rafts and spines of welded breccia and massive lava are common, thrusting out of the talus and locally increasing the slope of the front, and supporting frontal heights of between 12 and $20 \mathrm{~m}$.

\section{Discussion}

\section{5.a. Mega-features}

The 1999 lavas display a wide variety of morphologies, spanning the whole range of commonly observed basaltic lava features. Field structures vary strongly according to proximity to vent, underlying topography and local flow evolution. Even the most simple of nearvent or bocca channel sections tends to display two types of lava and three types of levees, and distal flow portions are more complex. The lavas were emplaced onto a landscape of varying relief and vegetation. Proximal site 1 flows were extruded from vents onto 
(a)

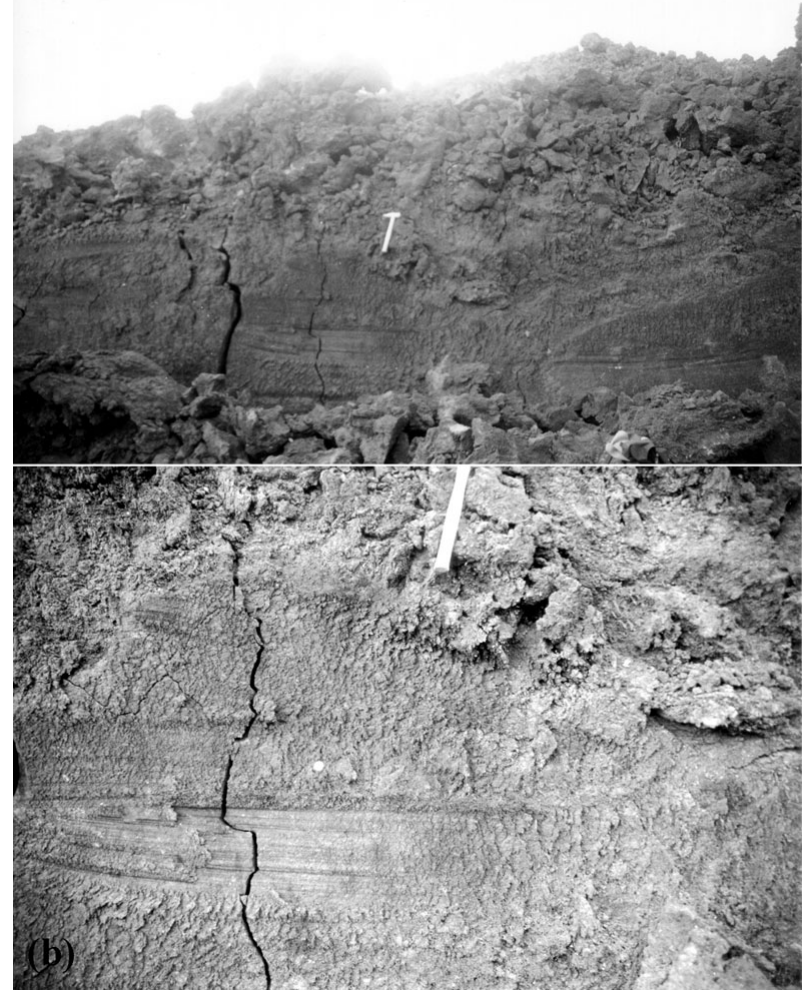

Figure 9. Squeeze-ups compressive features of the 1999 Mount Cameroon lava flows. (a) Ridge-like squeeze-up of clinkery aa emplaced between two adjacent lobes of blocky lava, in the site 2 distal flow region, near Bakingili. Irregular, spinose clinker overlies a massive avesicular interior. Hammer is $\sim 40 \mathrm{~cm}$ long. (b) Closer view of (a) showing thermally immature clinkertopped aa squeeze-up ridge. Massive, poorly vesiculated lava forms the main body of this feature and displays two welldeveloped lineations. fine near-horizontal striations parallel to the flow direction; and shallow, sub-vertical fractures typically a few centimetres deep. About $25 \mathrm{~cm}$ of hammer handle is visible.

gently sloping $\left(\sim 12^{\circ}\right)$ montane savannah, blanketed by recent ash or older flows. Burial of older lava was common, but older topographic features did not affect proximal flow evolution. The site 2 flows erupted at a lower altitude, closer to the upper limit of montane rainforest, and are more strongly guided by topography, forming several valley-fill sections closer to the vents.

The processes forming the above-described, largescale levee sequences result from interplay of flow conditions and parameters, including the source flux and its fluctuation, the rheological stiffening at the downstream flow-front, local outbreak-focused drainage, and heterogeneous channel flow regimes. With regards to lava profiles, those on steeper slopes preserve clear channel structures and single, as opposed to compound or multi-channel, flow units (Appendix 1 at http://www.cambridge.org/journals/geo). As slope decreases, lava is more able to spread laterally. Ponding typically occurs at sharp reductions in slope, in wells and rifts in the topography, and behind a stagnant flow front.

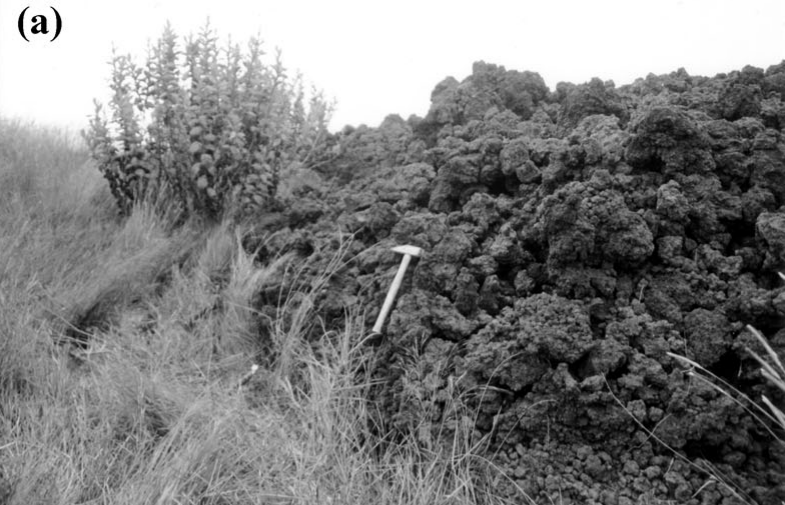

(b)
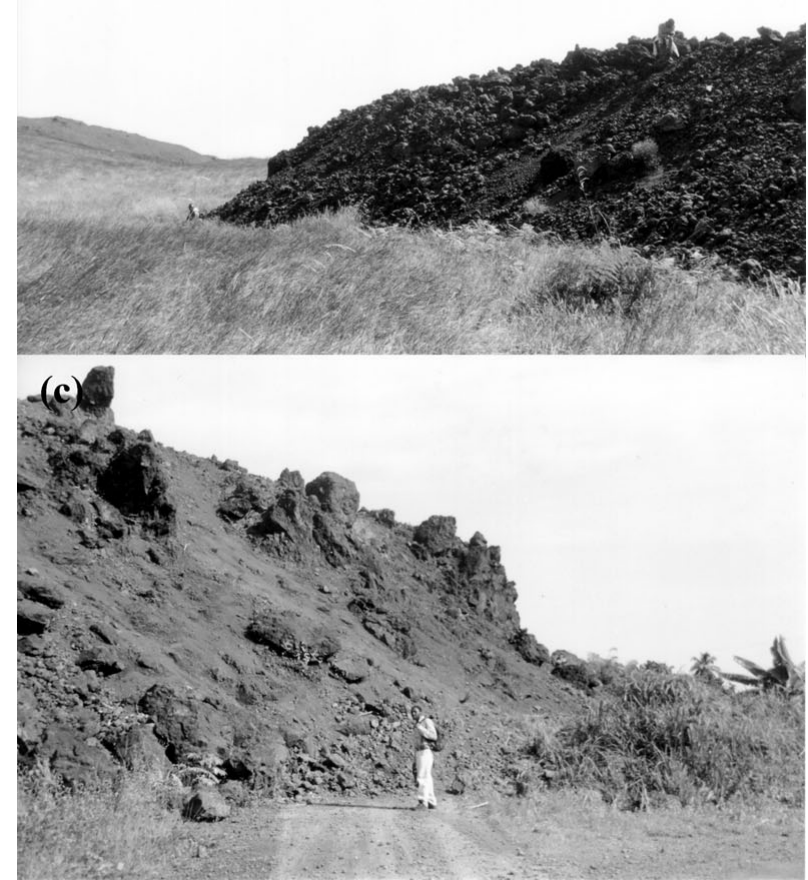

Figure 10. Principal characteristics of the lava flow fronts. (a) Site 1 aa flow front, consisting of a poorly sorted, partially disaggregated mix of clinkers, welded clinkers, large aa 'cauliflowers' (terminology after Kilburn, 1990) and finer brecciated material. The height of this small, thermally immature flow front is $1.7 \mathrm{~m}$; hammer length is $\sim 45 \mathrm{~cm}$. (b) Aa flow front, more thermally mature than that in (a). This small lobe from a blocky lava flow has developed a greater proportion of welded, rubbly material than superproximal aa. The men are $\sim 170 \mathrm{~cm}$ tall. (c) Flow front of a thermally mature Bakingili blocky flow that had overridden the Limbe-Idenau highway, typically composed of large rafts of welded rubble and a highly abraded fine talus.

\section{5.b. Lava surface types}

Lava surface characteristics are varied according to the thermal maturity of the flow surface itself (Naranjo et al. 1992). When erupted from a vent or bocca, cooling rapidly changes the surface regions of the lava from an incandescent fluid with increasing levels of plasticity to a cooled, brittle solid (Ball, Pinkerton \& Harris, 2008). If the flow ceases motion before the 
surface becomes sufficiently cooled to deform by semiductile or brittle mechanisms then smooth pahoehoe surfaces are preserved. With further cooling and crustal thickening, deformation can no longer be accommodated in a ductile manner, and consequently lava surfaces tear, disaggregating first into slabs and rafts, then into clinker, and ultimately into angular blocks.

With cooling, groundmass microlite content increases and crystal-fluid and crystal-crystal interactions become more frequent. As this process continues, there is a gradual transition from ductile to brittle behaviour. It is during this transitional process that aa lava surfaces form (Moore, 1987; Kilburn, 1990; Rowland \& Walker, 1990; Jaggar, 1930, Peterson \& Tilling, 1980). In laminar flow the central region of the channel moves faster than the flow margins where shear is highest. Thus lava surfaces in the centre have experienced less cooling and less shearing than lava surfaces at the channel margins (Flynn \& MouginisMark, 1994; Bailey et al. 2006). As a consequence, the flow centre can remain as pahoehoe, whereas the cooler and more sheared margins develop an aa clinker texture as illustrated in Figure 3a.

As lava evolves further, and develops a cooler, thicker crust, the tensile and shear stresses that build in a flow are accommodated by brittle failure. As the lava becomes more thermally mature the depth of solidductile transition increases, and the most thermally mature lavas are produced, with surface analogous to the flows of Macdonald (1953). Although blocky flows are commonly associated with the more viscous lavas of andesite and rhyolite flows (Macdonald, 1953), primarily as a function of their slower emplacement times (and hence opportunity to thermally mature), they are also witnessed at long-lived basaltic flows (e.g. Booth \& Self, 1973; Keszthelyi \& Self, 1998; Harris et al. 2009 and references therein), as documented in this study. The upper surface of the flow as well as an increasing fraction of the marginal flow interior deform more as a granular flow, with blocks milling, fracturing and rearranging to accommodate channel movement.

\section{5.c. Implications of levee structures: modes of formation}

Irrespective of their post-eruption propensity, initial levees form a protostructure that can be masked or altered by subsequent levee-building processes (Harris et al. 2009). Hulme (1974) argues that lateral spreading is eventually inhibited by the development of nonNewtonian properties in the marginal lava with the basal shear stress falling below the yield strength. Following the development of initial levees, the focus of flow down a channel produces high rates of shear at the levee-channel interface. The newly erupted lava is sheared too quickly to form fluid pahoehoe, and instead accommodates deformation in a plastic manner, forming small, irregular clinkers (Peterson \& Tilling, 1980; Keszthelyi \& Self, 1998). With the generally parabolic profile of the flow kinematics, modified by an added lateral component supplied by a typically convex-upwards surface, hot and plastic marginal clinkers are accreted together along the initial levee margins, further developing the levee structure.

Sparks, Pinkerton \& Hulme (1976) argued that accretionary levees form through a 'steady, slow rise of lava level'. Such an increase may arise from an increase in the effusion rate, or from the cooling of more distal regions, especially the flow front. As already discussed, the slower-moving channel margins will display the effects of cooling preferentially to the more mobile interior. The two factors promoting accretion are both greatest at the upper portions of the channel sides: shear, aiding the smearing and consolidation of clinkers, and cooling, which promotes the solidification and stabilization of the levee. Successive rises in flow level will thus accrete material from the channel, and build outwardly sloping inner walls unless a flow surge or blockage downstream causes a more rapid rise, in which case overflows will likely occur (Harris et al. 2009). There is often considerable interplay between initial, accretionary and overflow levee-building processes. In the 1999 Mount Cameroon lava flows, pahoehoe overflows overlie much of the welded clinker, indicating a later, possibly surge-fed genesis. Areas of welded material overlie more massive lava, suggesting the accretionary constructs post-date, or are contemporaneous with, the initial levee-forming lava.

Rubble levees begin to form in response to the backpressure created by the rheologically stiffened flow front (Calavari \& Pinkerton, 1998; Bailey et al. 2006). As the front advances, the rheologically and texturally zoned material is pushed aside by the caterpillar motion of the cooled surface, aided by the mobile fluid interior (Peterson \& Tilling, 1980; Fig. 11a, b). This new flow front soon cools and brecciates, and is itself marginalized by more thermally immature material or, more commonly, the thermally developed flow surface, building marginal rubble levees which display a gradation from external rubble, through welded clasts into a sluggish visco-plastic interior. These structures are modified by the subsequent passage of warmer channelized lava. Additional material is provided by the transport of blocky material from the channel to the levee margins, and occasional 'blocky overflows' (similar to fluid overflow levees, only using clastic material). For the inner walls of the rubble levees, margin shear and lateral channel pressure will erode initially fractured material so that it degrades in size, and sorts through to the basal regions of the shear zone, forming an incipiently welded fine basal breccia. As downflow rheological changes cause a back-pressure to build up, resulting in flow thickening, and local narrowing of the channel as a function of cooling similarly occurs, the flow channel will inflate, and flow level will rise. The upper surface will accommodate this movement by blocky avalanching, further developing and thickening the angle of talus that develops on the levee outer slopes. Along the inner margin, the rise in level effectively raises the level of the hot, interior portion of the flow. 


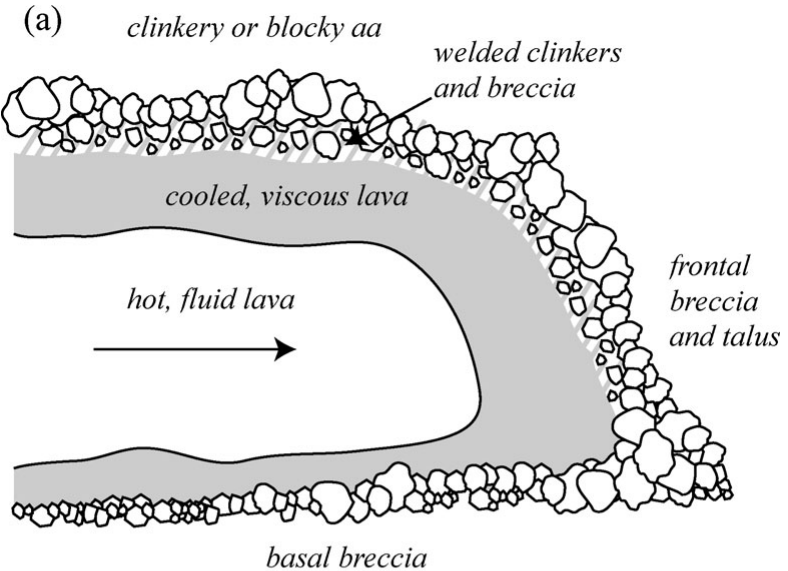

(b)

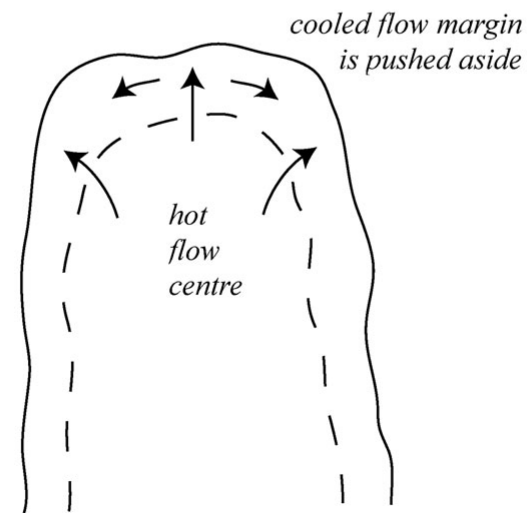

Figure 11. Structural and thermal zonation in blocky aa flows. Cooling causes initially Newtonian or weakly pseudoplastic material to stiffen, become increasingly non-Newtonian and ultimately cease behaving as a fluid, but pass into a regime of solid mechanics and brittle failure. As cooling is focused along the flow margins, and flow-top material is deposited at the flow toe by a caterpillar-like motion, frontal regions produce a flow profile similar to (a). While the core can deform in a ductile manner, the marginal carapace consists of torn clinkers and fractured blocks and rubble. The advance of the flow produces continual milling and further fracture; the high basal rates of shear and 'conveyor belt' style of advance of the flow front produce a similar layer of autobrecciated material on the flow base. As flow toe advances (b), the surface clinker or blocky aa pushes aside the sluggish, partially brecciated margins, whose structure forms the proto-rubble levees that are further developed by adjacent channel motion.

This serves to weld further the initial rubble and breccia that accumulated, giving the levee stability, and also welding newer, warmer clinker to the wall, in a manner similar to that displayed in an accretionary levee. When the lava reaches its maximum height, upwards building of the levees ceases. The material deposited at the top represents the youngest material accrued to the levee, consisting of cool, thermally mature blocky lava, deposited from the channel. A subsequent decrease in lava level will strand this material here and result in the rubble levee profile described at Mount Cameroon.

Overflow levees are generally formed following a flow surge or pulse, or a gradual rise in the lava level as a function of down-slope cooling (Sparks, Pinkerton \& Hulme, 1976; Bailey et al. 2006). They are generally thin and have limited extent, indicating they were supplied by pulses of short-lived liquid lava (Harris et al. 2009). Both pahoehoe drapes and aa overflows are relatively common in the 1999 flows, occasionally in the same flow, with pahoehoe most likely signifying a vent-induced surge of hotter, less thermally mature lava, and aa depicting a back-pressure-derived rise in marginal clinker. Aa overflows at Etna have been interpreted as being due to localized channel blockages. Also, the pahoehoe drapes for the 1999 lavas extend no more than $15 \mathrm{~m}$ from the channel and are usually $<1 \mathrm{~m}$ thick. This ties with observations at Etna (Bailey et al. 2006) and underlies the unsteady nature of flow within the channel.

\section{5.d. Significance of compressive structures}

Lava flows develop compressive stresses during emplacement as a result of slower speeds at the front than in the flow behind (see also Lister, 1992). As lavas are erupted onto complex topographies, local reduction in slope and ponding can result in a sudden decrease in the forward speed, and in a compressive regime. These compressive stresses are exacerbated by the process of cooling. Pahoehoe ropes typically form at temperatures of $700-800^{\circ} \mathrm{C}$ (Ball, Pinkerton \& Harris, 2008), when the crust is ductile enough to fold rather than fracture. In a cooled lava flow, the rheology of the crust is often different from that of the core and it is rheology of the crust that determines the final surface texture such as ropes (Guest \& Stofan, 2005).

Pressure ridges form as the lava surface accommodates to compressive stresses in the flow, usually where there is a break in slope. Squeeze-ups occur when the stress regime forces hotter material through the fractured or unconsolidated carapace, which then cools to form less thermally mature morphologies. Areas of relative weakness (e.g. highly brecciated surfaces) or those experiencing considerable pressure are natural sites for such structures to form. The squeeze-up displayed in Figure 9 was extruded from the well between two lava lobe toes. Such an area is higher than the adjacent, more sluggish lobe fronts, and experiences a greater hydrostatic pressure from the lava dammed behind. Along the channel margins, high rates of shear produce a brecciated flow surface with mobile lava underneath. Although we have inferred that marginal regions experience exacerbated cooling relative to the higher velocity centre, the crust is rapidly disaggregated, distinct from the poorly sheared, pluglike centre. Lava in these marginal regions is more freely able to squeeze through the carapace in response to surges or compression.

Pinnacles, spinacles or rafts are inferred to form from two processes. Many rafts appear to have originated as fragments of levee that have broken away as a function of post-drainage instability or channel pressure. Some rafts and pinnacles appear more rooted in the underlying lava, and may instead arise from the fracture and up-thrust of the solid or semi-solid material that 
underlies the blocky veneer. These forms are distinct from the tumuli and 'lava rise' described by Walker (1991). Their prominence in the centres of channels, that have experienced local inflation and back-pressure, indicates a mode of formation involving inflated crust rising and buckling as a function of compression, followed by rotation of the rafts or pinnacles to new geometries.

\section{Conclusions}

This contribution has presented detailed field analyses of the basic lava flows produced by the 1999 eruption of Mount Cameroon. Lava flows generated by both site 1 and site 21999 activity were systematically mapped and profiled, producing the sections presented in this work. This research constitutes the first major appreciation of the character and dynamics of the 1999 lava flows, and analyses their genesis, development and habit in light of the literature on basaltic flow phenomena. Such literature largely formed from investigations of flows at Hawaii or Etna is pertinent, for Mount Cameroon exhibits many broadly similar eruption characteristics. The mega-, macro-scale morphologies of the 1999 lava flows display the suite of basic flow-types. The concept of thermal maturity, especially developed by Naranjo et al. (1992), is used to great extent in categorizing and understanding Mount Cameroon flow phenomena, from the proximal, thermally immature pahoehoe with early-stage levee formation, through the development of clinker aa, to the ultimate development of thermally mature, blocky products in the distal flow regions.

In addition to using the existing literature to inform analyses of Mount Cameroon, the 1999 flows offer opportunities to define flow phenomena further, or offer examples distinct to basaltic flow 'archetypes' that allow for expansion of the literature with Cameroonian examples. This is true in the case of ubiquitous features, such as levees and lava channels, which are commonly described yet relatively little understood. Abundant levees on Mount Cameroon allowed dedicated, qualitative analyses of levee formation for long lava flows, particularly in the case of distal, rubbly levees to be formulated, producing analyses that expand upon the work of Sparks, Pinkerton \& Hulme (1976) and Naranjo et al. (1992) to better describe levee processes.

Acknowledgements. This contribution is an outcome of the British Council-funded Higher Education Link Project 'Understanding the Environment of Mount Cameroon' between the Universities of Bristol and Buea. RSJS and GGJE acknowledge travel grants from the Royal Society for the field work. CES and MSN also gratefully acknowledge funding from the Faculty of Science (University of Buea) Research Grant Scheme to support their work on Mount Cameroon. GGJE is now supported by the Belgian NSF (FWO-Vlanderen) where he is also developing $\mathrm{MC}$ research funded by a VLIR-OI project coordinated by P. Jacobs at UGhent. We appreciate the comments of two anonymous Geological Magazine reviewers and the editorial guidance of David Pyle.

\section{References}

Bailey, J. E., Harris, A. J. L., Dehn, J., Calavari, S. \& RowLAND, S. 2006. The changing morphology of an open lava channel on Mt. Etna. Bulletin of Volcanology 68, 497-515.

BAll, M., Pinkerton, H. \& HARRis, A. J. L. 2008. Surface cooling, advection and the development of different surface textures on active lavas on Kilauea, Hawaii. Journal of Volcanology and Geothermal Research 173, $148-56$.

Booth, B. \& SELF, S. 1973. Rheological features of the 1971 Mount Etna lavas. Philosophical Transactions of the Royal Society, London A274, 99-106.

CAlaVARI, S. \& PinKERTON, H. 1998. Formation of lava tubes and extensive flow field during the 1991-1993 eruption of Mount Etna. Journal of Geophysical Research, Solid Earth 103, 27291-301.

CALAVARI, S. \& PinKerTON, H. 1999. Lava tube morphology on Etna and evidence for lava flow emplacement mechanisms. Journal of Volcanology and Geothermal Research 90, 263-80.

Cashman, K. V., Thornber, C. R. \& Kauahikaua, J. P. 1999. Cooling and crystallization of lava in open channels, and the transition of Pahoehoe lava to aa. Bulletin of Volcanology 61, 306-23.

Deruelle, B., Ngounouno, I. \& Demaiffe, D. 2007. The 'Cameroon Hot Line' (CHL): a unique example of active alkaline intraplate structure in both oceanic and continental lithospheres. Comptes Rendus Geoscience 339, 589-600.

FINK, J. H. 1980. Surface folding and viscosity of rhyolite flows. Geology 8, 250-4.

FINK, J. H. \& FLETCHER, R. C. 1978. Ropy pahoehoe: surface folding of viscous fluid. Journal of Volcanology and Geothermal Research 4, 151-70.

FitTon, J. G. 1987. The Cameroon Line, West Africa: a comparison between oceanic and continental alkaline volcanism. In Alkaline igneous rocks (eds J. G. Fitton \& B. G. J. Upton), pp. 273-91. Geological Society of London, Special Publication no. 30.

Fitton, J. G. \& Hughes, D. J. 1977. Petrochemistry of volcanic rocks of the Island of Principe, Gulf of Guinea. Contributions to Mineralogy and Petrology 64, 25772.

Fitton, J. G., Kilburn, C. R. J., ThiRwall, M. F. \& Hughes, D. J. 1983. 1982 eruption of Mount Cameroon, West Africa. Nature 306, 5941, 327-32.

FLYNN, L. P. \& MOUGINIS-MARK, P. 1994. Temperature of an active lava channel from spectral measurements, Kilauea volcano, Hawaii. Bulletin of Volcanology 56, 297 301.

GregG, T. K. P., FInK, J. H. \& Griffiths, R. W. 1998. Formation of multiple fold generations on lava flow surfaces: influence of strain rate, cooling rate and lava composition. Journal of Volcanology and Geothermal Research 80, 281-92.

Guest, J. E., Kilburn, C. R. J., Pinkerton, H. \& DUNCAN, A. M. 1987. The evolution of lava flowfields: observations of the 1981 and 1993 eruptions of Mount Etna, Sicily. Bulletin of Volcanology 49, 52740.

Guest, J. E. \& Stofan, E. R. 2005. The significance of slab-crusted lava flows for understanding controls on flow emplacement at Mount Etna, Sicily. Journal of Volcanology and Geothermal Research 142, 193206.

Halliday, A. N., Dickin, A. P., Fallick, A. E. \& Fitton, J. G. 1988. Mantle dynamics: a Nd, Sr, $\mathrm{Pb}$ and $\mathrm{O}$ isotopic 
study of the Cameroon Line Volcanic chain. Journal of Petrology 29, 181-211.

Harris, J. L., Favalli, M., Mazzarini, F. \& Hamilton, C. W. 2009. Construction dynamics of a lava channel. Bulletin of Volcanology 71, 459-74.

HuLME, G. 1974. The interpretation of lava flow morphology. Geophysical Journal of the Royal Astronomical Society 39, 361-83.

JAGGAR, T. A. 1930. Distinction between pahoehoe and aa or block lava. Volcano Letters 181, 1-4.

Keszthelyi, L. \& Self, S. 1998. Some physical requirements for the emplacement of long basaltic lava flows. Journal of Geophysical Research 10, 27447-64.

KILBURN, C. R. J. 1990. Surfaces of lava flow-fields on Mount Etna, Sicily: Morphology, rheology, crystallization and scaling phenomena. In Lava flows and domes: emplacement mechanism and hazard implications (ed. J. H. Fink), pp. 129-56. IAVCEI Proceedings in Volcanology, vol. 2. Berlin: Springer-Verlag.

Kilburn, C. R. J., Pinkerton, H. \& Wilson, L. 1995. Forecasting the behaviour of lava flows. In Monitoring active volcanoes: strategies, procedures and techniques (eds B. Mcguire, C. R. J. Kilburn \& J. Murray), pp. 346-68. London: University College London Press.

LipMAN, P. W. \& BANKs, N. G. 1987. Aa flow dynamics, Mauna Loa 1984. United States Geological Survey Professional Paper 1350, 1527-67.

LISTER, J. R. 1992. Viscous flows down an inclined plane from point and line sources. Journal of Fluid Mechanics 242, 631-53.

MACDONALD, G. A. 1945. Structure of aa lava flows. Bulletin of the Geological Society of America 56, 1179-80.

MACDONALD, G. A. 1953. Pahoehoe, aa and blocky lava. American Journal of Science 251, 169-91.

Marzoli, A., Piccirillo, E. M., Renne, P. R., Bellieni, G., IACUMIN, M., NyOBE, J. B. \& TONGWA, A. T. 2000. The Cameroon line revisited: petrogenesis of continental basaltic magmas from lithospheric and asthenospheric mantle sources. Journal of Petrology 41, 87-109.

Moore, H. J. 1987. Preliminary estimates of the rheological properties of the 1984 Mauna Loa lava. United States Geological Survey Professional Paper 1350, 1569-88.

NARANJo, J. A., SPARKS, R. S. J., StasiuK, M. V., MorenO, H. \& ABLAY, G. J. 1992. Morphological, structure and texture variations in the 1988-1990 andesite lava of Lonquimay Volcano, Chile $\left(38^{\circ} \mathrm{S}\right)$. Geological Magazine 129, 657-78.

Ngako, V., Nuonfang, E., AKa, F. T., Affaton, P. \& NnANGE, J. M. 2006. The North-South Paleozoic to Quaternary trend of alkaline magmatism from NigerNigeria to Cameroon: complex interaction between hotspots and Precambrian faults. Journal of African Earth Sciences 45, 241-56.

Ngounouno, I., Deruelle, B. \& Demaiffe, D. 2000. Petrology of bimodal Cenozoic volcanism of the Kapsiki plateau (northernmost Cameroon, Central Africa). Journal of Volcanology and Geothermal Research 102, 21-44.

Nuome, M. S., Suh, C. E., Sparks, R. S. J., Ayonghe, S. N. \& FitTon, J. G. 2008. The Mount Cameroon 1959 compound lava flow field: morphology, petrography and geochemistry. Swiss Journal of Geosciences 101, 8598.

Nono, A., Deruelle, B., Demaiffe, D. \& Kambou, R. 1994. Tchabal Nganha volcano in Adamawa (Cameroon): petrology of a continental alkaline lava series. Journal of Volcanology and Geothermal Research 60, 147-78.
Peterson, D. W. \& Tilling, R. I. 1980. Transition of basaltic lava from pahoehoe to aa, Kilauea volcano, Hawaii: field observations and key factors. Journal of Volcanology and Geothermal Research 7, 271-93.

PINKERTON, H. \& SPARKS, R. S. J. 1976. The 1975 sub-terminal lavas. Mount Etna: a case history of the formation of a compound lava field. Journal of Volcanology and Geothermal Research 1, 167-82.

POLACCI, M. \& PAPALE, P. 1997. The evolution of lava flows from ephemeral vents at Mount Etna: insights from vesicle distribution and morphological studies. Journal of Volcanology and Geothermal Research 76, 1-18.

PolacCI, M. \& PAPAle, P. 1999. The development of compound lava fields at Mount Etna. Physics and Chemistry of the Earth 24, 949-52.

Poudjom DJomani, Y. H., NnANGe, J. M., Diament, M., EBINGER, C. J. \& FAIRHEAD, J. D. 1997. Effective elastic thickness and crustal thickness variations in westcentral Africa inferred from gravity data. Journal of Geophysical Research 100, 22047-70.

ROEDDER, E. 1974. Activity of iron and olivine solubility in basaltic liquids. Earth and Planetary Science Letters 23, 397-410.

Rowland, S. K. \& WalKer, G. P. L. 1990. Pahoehoe and aa in Hawaii: volumetric flow rate controls the lava structure. Bulletin of Volcanology 52, 631-41.

Self, S., Jay, A. E., Widdowson, M. \& Keszthelyi, L. P. 2008. Correlation of the Deccan and Rajahmundry Trap lavas: are these the longest and largest lava flows on Earth? Journal of Volcanology and Geothermal Research 172, 3-19.

Self, S., Keszthelyi, L. \& Thordason, T. 1998. The importance of pahoehoe. Annual Review of Earth and Planetary Sciences 26, 81-110.

SHAW, H. R. 1972. Viscosities of magmatic silicate liquids: an empirical model of prediction. American Journal of Science 272, 438-75.

Soule, S. A., Cashman, K. V. \& Kauahikaua, J. P. 2004. Examining flow emplacement through the surface morphology of three rapidly emplaced solidified lava flows, Kilauea volcano, Hawaii. Bulletin of Volcanology 66, 1-14.

Sparks, R. S. J., Pinkerton, H. \& Hulme, G. 1976. Classification and formation of lava levees on Mount Etna, Sicily. Geology 4, 269-71.

SuH, C. E., LuHR, J. F. \& NuOME, M. S. 2008. Olivinehosted glass inclusions from scoriae erupted in 19542000 at Mount Cameroon volcano, West Africa. Journal of Volcanology and Geothermal Research 169, 1-33.

Suh, C. E., Sparks, R. S. J., Fitton, J. G., Ayonghe, S. N., Annen, C., NanA, R. \& Luckman, A. 2003. The 1999 and 2000 eruptions of Mount Cameroon: eruption behviour and petrochemistry. Bulletin of Volcanology 65, 267-81.

Toteu, S. F., Penaye, J. \& Poudjom Djomani, Y. P. 2004 Geodynamic evolution of the Pan-African belt in central Africa with special reference to Cameroon. Canadian Journal of Earth Sciences 41, 73-85.

WALKER, G. P. L. 1991. Structure and origin by injection of lava under surface crust, of tumuli, 'lava rise', 'lavarise pits' and 'lava-inflation clefts' in Hawaii. Bulletin of Volcanology 53, 546-58.

WANDJI, P., TSAFACK, J. P. F., BARDINTZEFF, J. M., Nkouathio, D. G., Kagou Dongmo, A., Bellon, H. \& GuILlOU, H. 2009. Xenoliths of dunites, wehrlites and clinopyroxenites in basanites from Batoke volcanic cone (Mount Cameroon, central Africa): petrogenetic implications. Mineralogy and Petrology 96, 81-98. 